\title{
Information on the Activities of the Counselogical Association
}

\author{
Jozef Kargul \\ The University of Lower Silesia, Wroclaw, Poland
}

\begin{abstract}
In Poland, there has established a new sub-discipline of social science that is being labeled as counselogy and created by Alicja Kargulowa. The main research object of counselogy is counselling, broadly understood, and therefore, counselogy deals with the analysis of psychological counselling, career counselling, family counselling, marriage counselling, education counselling, bank counseling, etc.. This text contains information on establishing the elitist Counselogical Association. There are the counselogists and counselling researchers among the members of this association. A regular member may be a physical person holding an academic rank of at least Ph.D.. The mission of this association is research activity: initiating research projects, conducting international cooperation with academic centres, integrating counselogy experts, popularizing knowledge of counselogy by organizing conferences and emitting publications and cooperation with practitioners to introduce innovations into counselling.

Keywords: counselogy, counselling, association, research activity, cooperation with local environment, international cooperation
\end{abstract}

\section{Origins}

In the 1980s, the pedagogue Alicja Kargulowa together with clinical psychologist and Dr Prof. Marian Kulczycki offered individuals involved in various types of counselling in Poland the opportunity, independently of their respective disciplines, to come together. The purpose was not for them to discuss their counselling work, but rather to consider the possibility of developing a general theory of counselogy. This idea was warmly received by the counselling community, and from 1979 to 1995, seven multi-day seminars were held under the direction of Alicja Kargulowa. Participants came from both Poland and abroad.

The subjects of debate were language, terminology and definitions, based on the assumption that the language in which discourse is conducted can also have a deep effect on the construction of general reflections on the practice of counselling - a theory of counselling known as "counselogy".

Alicja Kargulowa's suggestion that the discourse on these practices avoided a narrow, mono-disciplinary perspective (psychological, pedagogical, legal, etc.), but rather undertook a new, interdisciplinary perspective on counselling, was not accepted without some resistance. However, her book, Counselling as Knowledge and a System of Actions: An Introduction to Counselogy (pub. Wrocław University, 1986), was well-received, as well as her book of 10 years later, Against Helplessness: Direction-Options-Controversies in Counselling and Counselogy. Alicja Kargulowa brought together a group of young researchers of counselling at the Universities of Wrocław and Zielona Góra, as well as the University of Lower Silesia, who approved of her way of thinking and reflecting on counselling, along with writing their own books and climbing the academic career ladder (two professors). Thanks to this, a counselogy school was founded, the only one in Poland at 
which the practice of counselling is viewed as one of many social activities and is analysed from an interdisciplinary perspective.

The position was accepted that "Theory is the groundwork for deliberations about the nature of the world, and, thus, remains separate from it" (Grobler, 2006), as its usefulness is not to be found in the natural manner in which it describes actual reality, but rather in its providing a framework for critical understanding of phenomena and bases for rationalizing their observed aspects. Such a theory is common knowledge, constructed on methodological assumptions since the times of Kuhn, one may say about paradigms, and constitute the basis for generating and synthesising discoveries. This also leads to the application of the comparison of theory to a kaleidoscope or pair of glasses through which we look at the world around us "seeking in its relations between variables and values" (Babbie, 2008, p. 33), treating it as a sort of "permission to draw conclusions" (Grobler, 2006, p. 260), or as a tool of predicting and verifying hypotheses (Grobler, p. 264). A more understanding counselling science counselogy was placed in one of Alicja Kargulowa's (2004) more recent books, On the Theory and Practice of Counselling. Types of Counselogical Discourse, and by her students and admirers in a collective work titled Counselogy - A Continuation of the Discourse. Both books, published by Wydawnictwo Naukowe PWN (2009), are recommended as university textbooks and are located in all university libraries in Poland. In this way, a group of researcher/counselogists publishing the results of their research was formed: Bożena Wojtasik, Elżbieta Siarkiewicz, Wioletta Podgórna, Marcin Szumigraj, Alicja Czerkawska, Daria Zielińska-Pękał, Joanna Minta and others.

At the same time, counselogists conducting research noticed that since the mid-1990s, a "counselling boom" had taken place. "Advisors" and "consultants" were appearing everywhere: at the bank, there is a "client counsellor", at the auto garage a "service advisor", there are "tax advisors", "nutritional counsellors", etc., and "counselling centres" are spreading like wildfire. Such a situation gave rise to a need to educate counsellors, which was taken up immediately by private institutions of higher education. Thus, such courses and specialties were introduced as "counselling", "advising", etc.. Focus was primarily on the methodology of counselling. Not always did they take care to ensure a competent teaching staff. Observation of these phenomena motivated counselogists to found the Counselogical Association, which was listed in the National Court Register in 2011.

\section{Mission}

The association is a politically neutral, voluntary, self-governing and independent non-profit association, respecting the right of each individual to his/her owns convictions and points of view, and the right to freedom of academic inquiry.

The mission of the members of the Counselogical Association is to be active in research: initiating counselogical research projects, conducting international cooperation with academic centres, integrating counselogy experts, popularizing knowledge of counselogy by organizing conferences and emitting publications and cooperation with practitioners to introduce innovations into counselling. The second area of activity concerns education: development and assessment of educational counselling programs conducted in courses and training sessions, bachelor, master and post-graduate studies, and also organizing and conducting various educational activities addressed to students, university teachers, advisors and other individuals performing advisory functions while employed by counselling institutions in the educational, labour and NGO (non-governmental) sectors.

Accomplishing this goal consists of initiating and conducting academic research and disseminating the 
results, by such means as publishing a bilingual (Polish-English) journal "Journal of Counselogy". The authors intend to expand substantive cooperation with local and national governmental authorities, institutions of higher education, scientific institutions and other domestic and international institutions. They plan to initiate and conduct commercial activity in accordance with applicable legal regulations in order to ensure financial support for the undertaking of the association's statutory tasks.

\section{Membership}

The founders of the association determined that it must possess certain elitist characteristics in order to fulfil its mission and accomplish its declared goals. This is why the association's statue contains the following statement:

A regular member may be a physical person possessing full legal capacity and full civil rights, holding an academic rank of at least Ph.D. or involved in academic work, identifying with the goals of the association, as well as declaring readiness to assist in the realization of its statutory goals.

\section{Authorities and Organizational Structure}

The highest authority of the association is the "General Assembly of the Association's Members", which selects the members of the Board of Directors - its chairperson, two vice-chairperson, secretary and treasurer, whose terms of office last for three years. The Board of Directors undertakes defined decisions concerning its activities.

The Board of Directors has decided to form sections, delineating particular areas in which individual members, in accordance with their interests and competences, can take initiative and be active. These are the names and tasks of the sections:

(1) Publishing Section: creators of "Journal of Counselogy", prof. Alicja Kargulowa (e-mail: j.kargul@dswe.pl);

(2) International Cooperation Section: establishing and conducting cooperation with international representatives involved in counselling research, following interesting scientific happenings abroad and reporting on them, prof. Bożena Wojtasik (e-mail: bwo@dswe.pl; wojtasik@ps.com.pl);

(3) Research and Educational Project Section: initiating and organizing activities related to conducting research on counselogy, creating educational projects, following interesting scientific happenings in Poland and reporting on them, Dr. Marcin Szumigraj (mszumigraj@wp.pl);

(4) Cooperation with Practitioners Section: undertakings intending to establish cooperation with advisors, counselling centres and management of governmental and non-governmental institutions, Dr. Barbara Skałbania (skalbania@op.pl);

(5) Media Section: conducting marketing activities related to promotion of the ACS (association of cancelling science), Dr. Anetta Pereświet-Sołtan (anettka13@gmail.com).

\section{Activities}

During the initial months, the work of the Association's Board of Directors was focused on formal and organizational matters.

In this same time, the Board of Directors decided to direct correspondence to three ministers: the Minister of Education, the Minister of Science and Higher Education and the Minister of Labour and Social Policy. In 
these letters, The authors provided information about the association's mission and offered specific services. The Minister of Education very quickly responded to declare that they Association would be entered into a list of social partners with whose consultations will be conducted during the creation of documents and solutions relating to professional counselling in the educational system.

Thanks to the activity of the PR (public relations) section (and especially its leader) and the cooperation with practitioners section, employees of psychological/pedagogical advisory centres and school career counsellors were informed of the existence of our association during conferences organized by the Ministry of Education.

The author thinks that the inspiration and activity of the association will lead to the conducting of further studies on counselling, and the knowledge thus gained will have a positive effect by improving the standard of counselling practices.

It is also our hope that the association may have the chance to be a member of a European or worldwide association bringing together other organizations involved in research on counselling.

\section{References}

Babbie, E. (2008). The basics of social research (3rd ed.) Polish edition. Wydawnictwo Naukowe PWN (Polish Scientific Publishers PWN), Warsaw.

Grobler, A. (2006). Methodology of sciences. Wydawnictwo Aureus, Krakow. 